\title{
The success of endotracheal intubation with a modified laryngoscope using night vision goggles
}

\author{
Attila Aydın, M.D., ${ }^{1}$ Sedat Bilge, M.D., ${ }^{1}$ Cemile Aydın, M.D., ${ }^{2}$ Meltem Bilge, M.D., ${ }^{3}$ \\ Erdem Çevik, M.D., ${ }^{4}$ Mehmet Eryılmaz, M.D. ${ }^{1}$ \\ ${ }^{1}$ Department of Emergency Medicine, Gülhane Training and Research Hospital, Ankara-Turkey \\ ${ }^{2}$ Department of Internal Medicine, Ankara Etimesgut State Hospital, Ankara-Turkey \\ ${ }^{3}$ Department of Anesthesiology and Reanimation, Dışkapı Training and Research Hospital, Ankara-Turkey \\ ${ }^{4}$ Department of Emergency Medicine, Sultan Abdülhamit Training and Research Hospital, İstanbul-Turkey
}

\begin{abstract}
BACKGROUND: Endotracheal intubation (ETI) procedure in the combat area differs from prehospital trauma life support procedures because of the danger of gunfire and the dark environment. We aimed to determine the success, difficulty degree, and duration of ETI procedures with a classical laryngoscope $(\mathrm{CL})$ in a bright room and with a modified laryngoscope (ML) model in a dark room.

METHODS: All interventions were performed by a combatant medical staff of 10 members. We developed an ML model to obtain a tool that can be used in combination with night vision goggles (NVGs) to perform ETI at night. The procedures were performed using a $C L$ with the naked eye in a bright room and using a ML with NVGs in a dark room. The ETI procedure that used the ML was performed by engaging and locking the blade on the handle either in the mouth (ML-IM) or outside of the mouth (ML-OM).
\end{abstract}

RESULTS: The mean completion times for the ETI procedures, namely Day-CL, ML-OM+NVG, and ML-IM+NVG, performed by the operators were 14.46, 26.9, and $32.38 \mathrm{~s}$, respectively. The ML-OM+NVG and ML-IM+NVG procedures were significantly longer than the Day-CL procedure $(p<0.05)$. The $M L-I M+N V G$ procedure was significantly longer than the $M L-O M+N V G$ procedure $(p<0.05)$. All ETI procedures were found to be $100 \%$ successful. The Day-CL procedure was easier than the ML-OM+NVG and ML-IM+NVG procedures $(\mathrm{p}>0.05)$.

CONCLUSION: The ETI procedure is applicable using NVGs in dark conditions on the battlefield. Medical interventions performed using NVGs in the dark should be a part of the basic training provided in tactical emergency medicine.

Keywords: Battlefield; darkness; endotracheal intubation; night vision goggles.

\section{INTRODUCTION}

Airway obstruction, life-threatening hemorrhages, and tension pneumothorax are preventable causes of death in the combat area. ${ }^{[l]}$ Endotracheal intubation (ETI) is a definitive and life-saving procedure, which maintains the patency of the airway. ${ }^{[1-3]}$ In addition, prehospital ETI is the gold standard and potentially life-saving maneuver if the patient's Glasgow Coma Scale score is $<8 .{ }^{[4]}$ All medical interventions in the combat area differ from prehospital trauma life support pro- cedures due to the risk of gunfire by enemy forces and the dark environment. In the emergency medical services system, prehospital ETI is used with varying success rates, and it is well-known that the type of trauma (i.e., facial trauma, hemorrhage, etc.), personnel, environmental factors, and equipment further complicate ETI in the combat area. ${ }^{[5]}$

Butler et al. ${ }^{[6]}$ reported an Israeli combat medic who was shot by a sniper while performing ETI at night. This previously reported study is a tragic illustration of the harm and damage

Cite this article as: Aydın A, Bilge S, Aydın C, Bilge M, Çevik E, Eryılmaz M. The success of endotracheal intubation with a modified laryngoscope using night vision goggles. Ulus Travma Acil Cerrahi Derg 2018;24:97-103

Address for correspondence: Attila Aydin, M.D.

Gülhane Eğitim ve Araştırma Hastanesi, Acil Tıp Kliniği, Ankara, Turkey

Tel: +90 312 - 3042000 E-mail: drattilaaydin@gmail.com

Ulus Travma Acil Cerrahi Derg 2018;24(2):97-103 DOI: 10.5505/tjtes.2017.27546 Submitted: 03.02.2017 Accepted: 29.06.2017 Online: 03.07.2017

Copyright 2018 Turkish Association of Trauma and Emergency Surgery 
that can be caused when an extra light source other than night vision goggles (NVGs) is used by paramedics/medics on the combat field. With the naked eye, the light of the classical laryngoscope $(\mathrm{CL})$ can be viewed; however, infrared (IR) light cannot be visualized unless observed with NVGs. There is still ongoing debate regarding the technical equipment that should be used while performing ETI in the dark environment of a combat area to avoid the limited visibility of the $C L$ and ensure safety.

In the present study, by replacing the $C L$ bulb with an IR lightemitting diode (IR-LED) bulb, we created a modified laryngoscope (ML) model to be used with NVGs while performing $\mathrm{ETI}$ in a dark environment. Thus, here we aimed to determine the success, difficulty degree, and duration of ETI procedures with a $C L$ in a bright room and with an $M L$ in a dark room.

\section{MATERIALS AND METHODS}

\section{Materials}

An endotracheal tube (Kendall, Cuffed tracheal tube, Switzerland, 2009), a 10-cc injector, Airway Management Manikin (Laerdal, Airway Management Trainer, Norway, 2013), lubricant gel, intubation stylet, silicone resuscitator with mouthpieces (Laerdal, Adult Standart, Norway, 20I3), and monocular NVGs (Aselsan, 983A, Turkey, 1995) were provided for the ETI procedure. All devices were used according to the manufacturer's instructions.

\section{CL}

A laryngoscope (Truphatek Macintosh, no. 3 Blade, Israel) and a blade bulb (5-mm external diameter, $2.5 \mathrm{~V}, 28 \mathrm{~mA}$, vacuumed nickel coating) were used.

\section{Formation of a New Laryngoscope Model}

Nickel coating of the CL bulb was transversely cut off while preserving the internal structures. The white light source was removed and replaced with an IR-LED light bulb (5-mm distal external diameter, I.6 V, $20 \mathrm{~mA}, 940 \mathrm{~nm}$ peak wavelength, $30^{\circ}$ view angle, convex lens), and the bulb was soldered to the previously cut bulb area and coated with silicon (Fig. Ia).

\section{Methods}

\section{Aim of The Method}

The study protocol with resuscitation manikins was approved by the Gülhane Military Medical Academy Ethics Committee. Our experimental study was performed on a resuscitation model in a simulated dark environment. In conflict environment with dark conditions, practitioners still use classical laryngoscopes for ETI procedures. Although NVGs are used in combat fields for tactical purposes (map reading, determination of enemy targets, etc.), it is routinely not used during ETI and other medical interventions. Military paramedics/ medics have to not only perform medical interventions on the combat field but also observe their environment while taking their NVGs off during battle. Therefore, it is essential for the practitioner to perform medical interventions, such as ETI, without removing NVGs in dark conditions. Because the light of CL can inevitably be seen with the naked eye of the enemy in dark conditions, we developed an ML model.

\section{Participants and Assessment Tool in Bright and Dark Rooms}

All interventions were administered by an experienced combatant medical staff (CMS) of 10 members who were trained in the Battlefield Advanced Trauma Life Support, which is a part of the military tactical training. All members had more than 5 years of experience in tactical emergency medicine and tactical night operations with NVGs. The operators used classical ETI and had not used ETI with NVGs before. This was a new technique. The operators were trained for the ETI procedure by military emergency medicine specialists (MEMS); these refreshment training programs (theoretical and practical), including anatomical landmarks and procedural tools, lasted for $60 \mathrm{~min}$ for each intervention.

The methods were performed using $C L$ with the naked eye in an illuminated area and using ML with NVGs in a dark
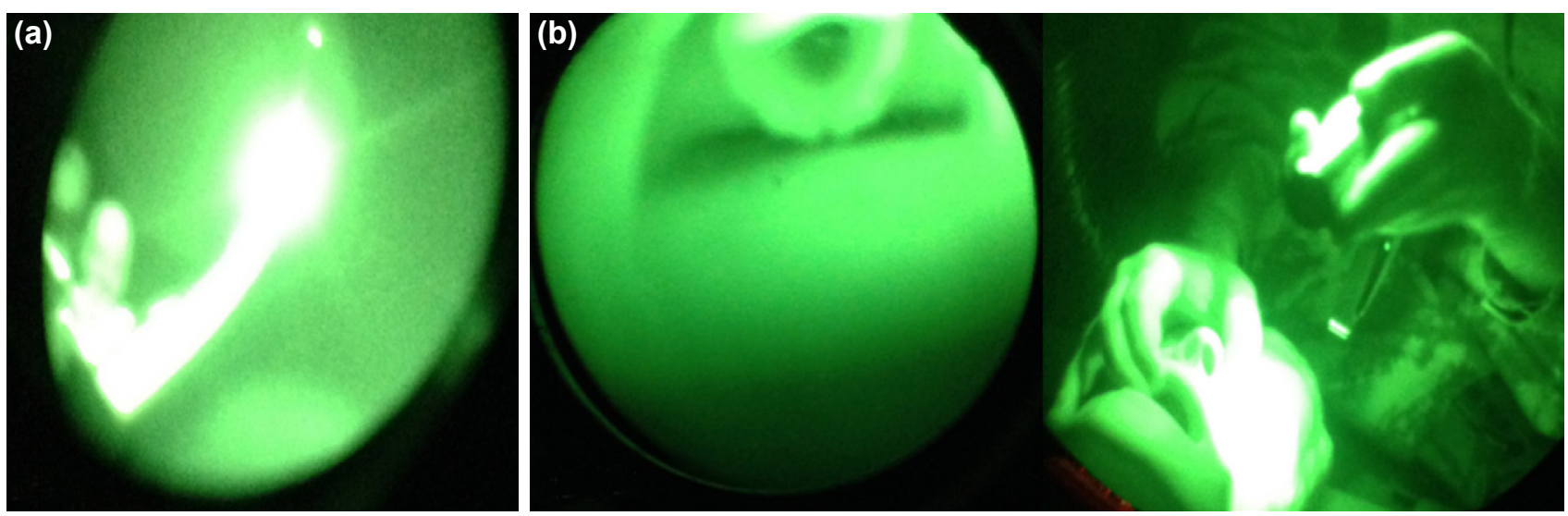

Figure 1. (a) View of the modified laryngoscope with infrared light-emitting diode lamp using night vision goggles. (b) Endotracheal intubation with the modified laryngoscope using night vision goggles and the view of vocal cords. 
room (Fig. Ib). The ETI procedure employing ML was performed by engaging and locking the blade on the handle either in the mouth (ML-IM) or outside of the mouth (ML$\mathrm{OM})$. To minimize the light filtering from the laryngoscope, the operators were instructed to loosely insert laryngoscope blades into the mouth (ML-IM) and then pull up the handle to visualize vocal cords. Using this approach, the anatomical structure of the oropharynx was used as a natural barrier to avoid light scattering. The following abbreviations were used in the corresponding circumstances: Day-CL, ETI using $C L$ in the daylight; ML-OM, locking the blade of ML on the handle out of the mouth in a dark room; and ML-IM, locking the blade of ML on the handle in the mouth in a dark room. The procedures performed with NVGs in a dark environment were indicated with "+NVG." The procedures performed in daylight (Day-CL) and in the dark room (ML-OM+NVG, $M L-I M+N V G)$ were randomized using research randomizer (www.randomizer.org). All methods were evaluated for their success and compared with each other. All operators repeated each intervention twice. The success, difficulty degree, and duration of ETI were explored in the study. No more than a single attempt was permitted for each insertion of the endotracheal tube (ETT), after which the procedure was considered as failed. Necessary steps for the success of the ETI procedure are shown in Table I. An unsuccessful procedure was defined as (a) taking more than $60 \mathrm{~s}$ to secure the airway, (b) no ventilation, (c) esophageal intubation, and (d) no lung inflation.

The duration of ETI was defined as the time from the preparation of the laryngoscope to the ventilation of the lungs, depending on the method selected by the participant. These parameters were observed by MEMS, and the results were recorded.
In addition, MEMS observed the success of the ETI procedure with the naked eye in daylight and using NVG in the dark room. Operators graded the ease of ETI (in bright and dark rooms) using a numerical rating scale with scores varying from I to 10, I0 for the most difficult interventions and I for very easy interventions.

\section{Statistical Analysis}

Statistical analysis was performed using SPSS for Windows version 22.0 (SPSS Inc., Chicago, IL, USA). Descriptive data were expressed in median values, standard deviation (minimummaximum). The Wilcoxon test was used to compare two groups, whereas the Friedman test was performed to compare more than two groups. Dual analyses were performed using the Bonferroni-corrected Wilcoxon test if the Friedman test revealed statistically significant differences. A p value of $<0.05$ was considered statistically significant. We calculated that a minimum of eight patients in each group would be required to detect a 20 -s difference between groups, assuming a standard deviation of $20 \mathrm{~s}$ with $80 \%$ power at an $\alpha$ level of 0.05 .

\section{RESULTS}

\section{Difficulty Degree of Procedures}

Operators $(n=10)$ rated the Day-CL procedure as easier than the ML-OM+NVG and ML-IM+NVG procedures $(p<0.05)$, and no significant difference was observed in difficulty between the ML-OM+NVG and ML-IM+NVG procedures $(p=I)$ (Tables 2 and 3).

\section{Success Rate}

All ETI procedures, namely Day-CL, ML-OM+NVG, and ML$I M+N V G$, performed by the operators were found to be $100 \%$ successful.

Table I. Mandatory steps for the success of the selected endotracheal intubation procedure

Endotracheal intubation procedure

\begin{tabular}{lll}
\hline Day-CL ML-OM + NVG & ML-IM + NVG
\end{tabular}

(a) Engagement of blade on the handle of $\mathrm{CL}$

(b) Handle pull blade up

(c) Insertion of ETT into the trachea

(d) Inflation of cuff

(e) Observation of the expansion of the lungs in the mannequin with silicone resuscitator by MEMS (a) Engagement of blade on the handle of ML

(b) Handle pull blade up out of the mouth

(c) Insertion of ETT into the trachea

(d) Inflation of cuff

(e) Observation of the expansion of the lungs in the mannequin with silicone resuscitator by MEMS (a) Engagement of blade on the handle of $M L$

(b) After loose insertion in the mouth pull blade up

(c) Insertion of ETT into the trachea

(d) Inflation of cuff

(e) Observation of the expansion of the lungs in the mannequin with silicone resuscitator by MEMS

Day-CL: Endotracheal intubation performed with a classical laryngoscope and naked eye in daylight in a bright room; ML-OM + NVG: Endotracheal intubation performed with a modified laryngoscope with the blades locked on the handle out of the mouth in a dark room using night vision goggles; ML- IM + NVG: endotracheal intubation performed with a modified laryngoscope with the blades locked on the handle in the mouth in a dark room using NVG; NVG: Night vision goggles; CL: Classical laryngoscope; ML: Modified laryngoscope; ETT: Endotracheal tube; MEMS: Military Emergency Medicine Specialist. 
Table 2. Intubation results

\begin{tabular}{lcccc}
\hline Scenario & Intubation success & $\begin{array}{c}\text { Intubation time (sec) } \\
\text { Mean } \pm \text { SD, min-max }\end{array}$ & $\begin{array}{c}\text { No of attempts } \\
\text { (Mean) }\end{array}$ & $\begin{array}{c}\text { Numerical rating scale } \\
\text { (Mean) }\end{array}$ \\
\hline Day-CL & $100 \%$ & $14.46 \pm 2.31(I I .7-17.9)$ & $1.0(0)$ & $1.5 \pm 0.5(I-2)$ \\
ML-OM + NVG & $100 \%$ & $26.90 \pm 2.77(23.3-32.7)$ & $1.0(0)$ & $5.9 \pm 0.7(5-7)$ \\
ML- IM + NVG & $100 \%$ & $32.38 \pm 2.10(28.8-35.1)$ & $1.0(0)$ & $5.9 \pm 0.7(5-7)$ \\
\hline
\end{tabular}

NRS: Numeric rating scale; Day-CL: Endotracheal intubation performed with a classical laryngoscope and naked eye in daylight in a bright room; ML-OM + NVG: Endotracheal intubation performed with a modified laryngoscope with the blades locked on the handle out of the mouth in a dark room using night vision goggles; ML- IM + NVG: Endotracheal intubation performed with a modified laryngoscope with the blades locked on the handle in the mouth in a dark room using night vision goggles; NVG: Night vision goggles; SD: Standard deviation.

Table 3. Comparison of intubation techniques

\begin{tabular}{|c|c|c|}
\hline \multirow[b]{2}{*}{ Comparison } & \multicolumn{2}{|c|}{ p value } \\
\hline & $\begin{array}{c}\text { Intubation } \\
\text { Time }\end{array}$ & NRS \\
\hline Day-CL vs ML-OM + NVG & $=0.005$ & $=0.004$ \\
\hline Day-CL vs ML-IM + NVG & $=0.005$ & $=0.005$ \\
\hline ML- OM + NVG vs ML-IM + NVG & $=0.005$ & $=1$ \\
\hline \multicolumn{3}{|c|}{$\begin{array}{l}\text { NRS: numeric rating scale; Day-CL: Endotracheal intubation performed with a } \\
\text { classical laryngoscope and naked eye in daylight in a bright room; ML-OM + } \\
\text { NVG: Endotracheal intubation performed with a modified laryngoscope with the } \\
\text { blades locked on the handle out of the mouth in a dark room using night vision } \\
\text { goggles; ML- IM + NVG: Endotracheal intubation performed with a modified } \\
\text { laryngoscope with the blades locked on the handle in the mouth in a dark room } \\
\text { using night vision goggles; NVG: Night vision goggles. }\end{array}$} \\
\hline
\end{tabular}

\section{Completion Time for the Interventions}

The mean completion times for the ETI procedures, namely Day-CL, ML-OM+NVG, and ML-IM+NVG, performed by the operators in the bright and dark rooms were I4.46, 26.9, and $32.38 \mathrm{~s}$, respectively. On comparing, the completion times of the ML-OM+NVG and ML-IM+NVG procedures were found to be significantly longer than Day-CL procedure $(p<0.05)$. The ML-IM+NVG procedure was significantly longer than the ML-OM+NVG procedure $(p<0.05)$ (Tables 2 and 3$)$.

\section{DISCUSSION}

Rapid airway management by tactical medical providers is a key skill, which may affect the survival of injured soldiers and civilians. Advanced airway management is feasible in the modern combat setting. ${ }^{[7]}$ In civilian settings, the indications for airway management include traumas, such as traffic collision-induced blunt injuries, whereas in the military setting, they include penetrating facial, neck, and maxillofacial injuries; significant airway hemorrhage secondary to vascular injury; and airway obstruction. ${ }^{[3,8,9]} \mathrm{It}$ is, therefore, one of the most important steps in the combat setting to maintain a patent airway.

Considering the nature of the combat area, the ETI procedure is affected by the previous experiences and skills of the CMS; the difficulty of the procedure completion on the field; and factors such as darkness, excessive noise, access to the patient, transportation of the patient to a safe location, insufficient equipment, clinical condition of the patient (for instance, maxillofacial injuries, cervical trauma, etc.), and difficult airway. ${ }^{[10,1]]}$ All these factors are independent of each other and need to be addressed to improve the success of ETI and to ensure tactical safety. Among these independent factors affecting the success of ETI and tactical safety, the present study focused on problems that were likely to interfere with light discipline while performing ETI in darkness.

Military paramedics/medics also have to observe their environment without removing their NVGs during battle. When white/yellow light is used for ETI, there is a risk of the personnel performing the ETI procedure to be spotted by the enemy forces. ${ }^{[6]}$ Butler et al. reported an Israeli military health care personnel who was killed by a sniper fire while manipulating the laryngoscope to perform ETI at night. In addition, a possible disadvantage of using video laryngoscopes in a tactical environment may be the backlit video screens, which may increase intubation exposure in a low-light environment. ${ }^{[12]}$ The evaluation and management of the patient are highly dependent on good lighting conditions.

Strict blackout discipline is extremely important for the military and allied units. However, practicing ETI in a tactical light-restricted environment is still a matter of debate. Tactical NVGs can be utilized for determining wound characteristics and for performing relevant interventions at night. The study by Butler et al. is a tragic illustration of the harm and damage that can be caused when an extra light source other than NVGs is used by paramedics/medics on the combat field. Furthermore, there have been a few studies on the use of NVGs in airway interventions, including one on ETI with NVGs; ${ }^{[13]}$ one on emergency cricothyroidotomy with NVGs; ${ }^{[14]}$ and one on ETI with NVGs. ${ }^{[15]}$ These studies reported that NVGs might be used while performing these procedures in darkness. However, there are few studies that guide operators on the principles of performing ETI in the dark and on the success of this procedure. 
The light of a CL can be seen with the naked eye, whereas IR light is not visible to the naked eye. In the present study, the bulb of the CL blade was replaced with an IR-LED bulb for the operator to perform ETI with NVGs. Thus, we could test the success and completion time of ETI performed by CMS in darkness without removing NVGs. ETI procedures performed with ML were as successful as those performed with $C L$ in daylight, but there was a statistically significant difference in completion times between the two $(p<0.05)$.

The operators in the present study were also experienced in performing ETI with CL and in the tactical use of NVGs. However, this was their first time for performing ETI using ML and NVGs in darkness (ML-OM+NVG and ML-IM+NVG). We believe that this may have contributed to the differences in the completion times and success of ETI.

Prehospital ETI performed by the operators with limited experience increased mortality, whereas those performed by more experienced operators were associated with lower mortality rates. ${ }^{[16,17]}$ The success of prehospital ETI in the combat area also decreased the rate of preventable deaths. In another study on ETI in humans, Wang et al. ${ }^{[18]}$ reported prehospital first-pass intubation success rates to be approximately $70 \%$, whereas Deakin et al. ${ }^{[7]}$ reported $30 \%$ failure rate for ETI performed by non-physician personnel in the prehospital setting. In studies wherein ETI was performed on mannequins, Bahathiq et al. ${ }^{[16]}$ reported a first-pass intubation success rate of $68 \%$, Yun et al. ${ }^{[12]}$ reported that the success rate of ETI ranged from $96 \%$ to $100 \%$, and Gellerfors et al. ${ }^{[13]}$ reported a success rate of $100 \%$. The present study reports a success rate of $100 \%$. In this respect, the present study yielded consistent findings with the studies by Yun et al. and Gellefors et al., which can be attributed to the extensive clinical experience of the CMS personnel and to the fact that they practiced with ETI procedures on the same airway management manikins during daytime. On the other hand, the studies by Wang et al. and Deakin et al. were conducted on real patients and their ETI success rates were lower than those in our study. Bahathiq et al. used paramedics without previous experience on ETI and therefore obtained a low success rate. In addition, success rates of the ETI procedures performed in the dark room were as high as those of the ETI procedures performed in daylight, suggesting the importance of advanced skills of the CMS personnel in the tactical use of NVGs.

The mean time to ventilation in the ETI procedures performed on mannequins was reported as $31.5 \mathrm{~s}$ by Bahathiq et al., ${ }^{[16]} 63.3 \mathrm{~s}$ by Prekker et al., ${ }^{[8]} 26.1$ s by Yun et al., ${ }^{[2]} 16.5$ $s$ by Gellerfors et al., ${ }^{[13]}$ and 14.46 s in the present study. The findings of the present study are also consistent with those reported by Gellerfors et al. and Yun et al. Among studies that evaluated the ETI procedures performed in darkness using NVGs, Schwartz et al. ${ }^{[19]}$ reported a success rate of $91.7 \%$ in humans using an IR filter and monocular NVGs, whereas the rate of first-pass intubation was $46.1 \%$ and the procedure time was $188.2 \mathrm{~s}$ in the study by Brummer et al. ${ }^{[15]}$ using an additional light source (IR light) and monocular NVGs during ETI on mannequins. Furthermore, Gellefors et al. reported a success rate of $100 \%$ and a completion time of $26.9 \mathrm{~s}$ in ETI on mannequins using binocular NVGs. Similarly, the present study reports a success rate of $100 \%$ and time to ventilation of $26.9 \mathrm{~s}$ using monocular NVGs. The study by Schwartz et al. differs from the present study as they worked on human subjects and used different success criteria. They evaluated ETI as successful until five attempts. Therefore, our study is consistent with the study of Gellefors et al. in terms of the success rate and completion time. In contrast to our study, however, in the study of Gellefors et al., ETI was performed by anesthesiologists using binocular NVGs. In addition, capnography verification was also performed between the ETI steps.

We suggest that CMS personnel should practice in dark environment and ML-OM+NVG/ML-IM+NVG trainings should be repeated frequently to reduce the time to ventilation in the ETI procedures. This would enable precise and rapid decisions by the personnel performing ETI in a combat setting and under dark conditions. The feedback received from the operators suggested that the Day-CL procedure was easier than the ML-OM+NVG and ML-IM+NVG procedures $(p<0.05)$. This finding was attributed to the fact that operators were not trained to perform ETI using NVGs and that they only had experience of performing ETI in daytime.

In routine practice, operators engage and lock the blade onto the handle to prepare the $C L$ for operation and to test if the lamp illuminates. During this preparation, illumination provided by the lamp inevitably reveals the operator's location to the enemy forces. To reduce illumination by the lamp, we demonstrated CMS personnel to deploy the blade into its locked position after inserting the blade loosely into the mouth and pulling up the blade to expose vocal cords. Via this maneuver, the anatomical structure of the oropharynx was used as a natural barrier to avoid light scattering. Schwartz et al. ${ }^{[19]}$ demonstrated the difficulty of performing intubation with monocular NVGs due to reduced depth perception. Despite that, in the present study, CMS personnel successfully (100\%) performed ETI using monocular NVGs in the dark environment; however, the feedback we received from the operators indicates that the ETI procedure performed with $M L$ is more difficult than the Day-CL procedure.

Based on the evidences from several healthcare disciplines, simulation can improve the knowledge (clinical decision making, patient assessment etc. and skill performance. We still require gaining excellence in using NVGs for medical interventions. Simulation training is an essential training strategy in healthcare systems to improve the patient's safety, and there are some evidences supporting that procedural simulation improves the actual operational performance in the clinical setting. The increasing trend of the use of simulation in 
healthcare training can be attributed to its many benefits. The ETI procedures and scenarios performed with ML-IM+NVG and $M L-O M+N V G$ in a room simulating dark conditions must be integrated into such simulation systems.

In a chaotic environment, we suggest that civilian healthcare workers involved in humanitarian relief services (Red Crescent, Red Cross, etc.) should deploy the CL blade in the mouth during intubation and perform the procedures under a lightproof cover if they lack facilities, such as NVGs. In night operations, we consider that advanced life support can be provided in the helicopter's cabin using night vision systems and laryngoscopes with IR-LED lamps, thereby eliminating the need for turning on lights.

Laryngoscope bulb manufacturers develop a product that diminishes the power of the IR light and focuses the light exclusively on the epiglottis and vocal cords. Instead of carrying a separate device that would add an additional weight into the medical packs, combat medics should have at their disposal IR-LED laryngoscope bulbs, such as the ML, designed in the present study, which should be kept at a location that is readily accessible to all personnel when required.

Nonetheless, there are some limitations to this study. First, the extent of the light reflected from the oropharynx of the human that becomes visible by the enemy forces remains unknown. Different challenges may occur in real-life practice as all ETI procedures in this study were performed on mannequins. In the real-life setting, the intubation may be complicated by blood and vomit in the airway and trismus. Second, auscultation with a stethoscope to confirm tracheal intubation may not be feasible due to excessive noise. Such challenges may affect the success and duration of the interventions. Therefore, further animal and human studies with challenging intubation mannequins are required to establish a conclusion.

\section{Conclusion}

In conclusion, ETI conducted in darkness using NVGs is a reliable method. Military paramedics/medics have to not only perform medical intervention on the combat field but also observe their environment without removing their NVGs during battle. Considering this finding, we believe that it would be relatively safer to open the $\mathrm{CL}$ blade inside the mouth and perform the procedure using NVGs. Medical interventions performed using NVGs in the dark should be a part of the basic training provided in tactical emergency medicine. Further studies conducted in battlefield area are needed to evaluate the safety and success of this procedure.

\section{Acknowledgement}

Dedicated in the memory of Lt. Col. İhsan EJDAR.

Conflict of interest: None declared.

\section{REFERENCES}

1. Mabry R, Frankfurt A, Kharod C, Butler F. Emergency Cricothyroidotomy in Tactical Combat Casualty Care.J Spec Oper Med 2015;15:11-9.

2. Bogdański Ł, Truszewski Z, Kurowski A, Czyżewski Ł, Zaśko P, Adamczyk P, et al. Simulated endotracheal intubation of a patient with cervical spine immobilization during resuscitation: a randomized comparison of the Pentax AWS, the Airtraq, and the McCoy Laryngoscopes. Am J Emerg Med 2015;33:1814-7. [CrossRef]

3. Bilge S, Aydin A, Eryilmaz M. Endotracheal intubation with tactical fiberoptic imaging systems. Am J Emerg Med 2016;34:664-5.

4. Kulla M, Helm M, Lefering R, Walcher F. Prehospital endotracheal intubation and chest tubing does not prolong the overall resuscitation time of severely injured patients: a retrospective, multicentre study of the Trauma Registry of the German Society of Trauma Surgery. Emerg Med J 2012;29:497-501. [CrossRef]

5. Schalk R, Byhahn C, Fausel F, Egner A, Oberndörfer D, Walcher F, et al. Out-of-hospital airway management by paramedics and emergency physicians using laryngeal tubes. Resuscitation 2010;81:323-6. [CrossRef]

6. Butler FK Jr, Holcomb JB, Giebner SD, McSwain NE, Bagian J. Tactical combat casualty care 2007: evolving concepts and battlefield experience. Mil Med 2007;172:1-19. [CrossRef]

7. Deakin CD, Peters R, Tomlinson P, Cassidy M. Securing the prehospital airway: a comparison of laryngeal mask insertion and endotracheal intubation by UK paramedics. Emerg Med J 2005;22:64-7. [CrossRef]

8. Prekker ME, Kwok H, Shin J, Carlbom D, Grabinsky A, Rea TD. The process of prehospital airway management: challenges and solutions during paramedic endotracheal intubation. Crit Care Med 2014;42:1372-8.

9. Kempema J, Trust MD, Ali S, Cabanas JG, Hinchey PR, Brown LH, et al. Prehospital endotracheal intubation vs extraglottic airway device in blunt trauma. Am J Emerg Med 2015;33:1080-3. [CrossRef]

10. Eastridge BJ, Mabry RL, Seguin P, Cantrell J, Tops T, Uribe P, et al. Death on the battlefield (2001-2011): implications for the future of combat casualty care. J Trauma Acute Care Surg 2012;73:S431-7. [CrossRef]

11. Mabry RL, Edens JW, Pearse L, Kelly JF, Harke H. Fatal airway injuries during Operation Enduring Freedom and Operation Iraqi Freedom. Prehosp Emerg Care 2010;14:272-7. [CrossRef]

12. Yun BJ, Brown CA 3rd, Grazioso CJ, Pozner CN, Raja AS. Comparison of video, optical, and direct laryngoscopy by experienced tactical paramedics. Prehosp Emerg Care 2014;18:442-5. [CrossRef]

13. Gellerfors M, Svensén C, Linde J, Lossius HM, Gryth D. Endotracheal Intubation With and Without Night Vision Goggles in a Helicopter and Emergency Room Setting: A Manikin Study. Mil Med 2015;180:100610. [CrossRef]

14. MacIntyre A, Markarian MK, Carrison D, Coates J, Kuhls D, Fildes JJ. Three-step emergency cricothyroidotomy. Mil Med 2007;172:1228-30.

15. Brummer S, Dickinson ET, Shofer FS, McCans JP, Mechem CC. Effect of night vision goggles on performance of advanced life support skills by emergency personnel. Mil Med 2006;171:280-2. [CrossRef]

16. Bahathiq AO, Abdelmontaleb TH, Newigy MK. Learning and performance of endotracheal intubation by paramedical students: Comparison of GlideScope $\left({ }^{(}\right)$and intubating laryngeal mask airway with direct laryngoscopy in manikins. Indian J Anaesth 2016;60:337-42. [CrossRef]

17. Diggs LA, Viswakula SD, Sheth-Chandra M, De Leo G. A pilot model for predicting the success of prehospital endotracheal intubation. Am J Emerg Med 2015;33:202-8. [CrossRef]

18. Wang HE, Yealy DM. Out-of-hospital endotracheal intubation: where are we? Ann Emerg Med 2006;47:532-41. [CrossRef]

19. Schwartz RB, Gillis WL, Miles RJ. Orotrachial intubation in darkness using night vision goggles. Mil Med 2001;166:984-6. [CrossRef] 
DENEYSEL ÇALIŞMA - ÖZET

\section{Gece görüş gözlükleri kullanarak modifiye laringoskopla endotrakeal entübasyon başarısı}

Dr. Attila Aydın, ${ }^{1}$ Dr. Sedat Bilge, ${ }^{1}$ Dr. Cemile Aydın, ${ }^{2}$ Dr. Meltem Bilge, ${ }^{3}$ Dr. Erdem Çevik, ${ }^{4}$ Dr. Mehmet Eryılmaz ${ }^{1}$

${ }^{1}$ Gülhane Eğitim ve Araştırma Hastanesi, Acil Tıp Kliniği, Ankara

${ }^{2}$ Ankara Etimesgut Devlet Hastanesi, l̇ç Hastalıkları Kliniği, Ankara

${ }^{3}$ Dışkapı Eğitim ve Araştırma Hastanesi, Anesteziyoloji ve Reanimasyon Kliniği, Ankara

${ }^{4}$ Sultan Abdülhamit Eğitim ve Araştırma Hastanesi, Acil Tıp Kliniği, Istanbul

AMAÇ: Karanlık ortamda düşman ateşi altında endotrakeal entübasyon (ETE) prosedürü hastane öncesi travma yaşam desteği prosedürlerinden farklıdır. Amacımız; aydınlık odada klasik laringoskop (KL), karanlık odada modifiye laringoskop (ML) modeli ile ETE prosedürlerinin başarı, zorluk derecesi ve ETE prosedür süresini ortaya çıkartmaktır.

GEREÇ VE YÖNTEM: Tüm girişimler 10 kişiden oluşan muharip sağlık personeli tarafından yapıldı. Gece koşullarında, gece görüş gözlükleri (GGG) ile ETE prosedürünün gerçekleştirmek için ML modeli geliştirdik. Girişimler; KL kullanılarak aydınlatılmış bir alanda ve ML ile GGG kullanılarak karanlıkta gerçekleştirildi. Modifiye laringoskop bıçağı ağız içinde (ML-Ail+GGG) veya ağız dışında (ML-AD+GGG) açılacak şekilde iki ayrı metod şeklinde kullanıldı.

BULGULAR: Uygulayıcılar tarafından aydınlık ve karanlık odada yapılan ETE girişimlerinin (Gündüz-KL, ML-AD+GGG, ML-AI+GGG) ortalama tamamlanma süreleri sırasıyla 14.46 sn., 26.9 sn., ve 32.38 sn. olarak saptandı. ML-AD+GGG ve ML-AI+GGG, Gündüz-KL'ye göre istatistiksel olarak anlamlı derecede daha uzundu ( $p<0.05)$. Modifiye laringoskop-AI+GGG, ML-AD+GGG'ye göre göre istatistiksel olarak anlamlı derecede daha uzun bulundu ( $\mathrm{p}<0.05)$. Bütün ETE girişimleri \% I00 başarılıydı. Gündüz-KL, ML-AD+GGG ve ML-Ail+GGG ile karşılaştırıldığında daha kolaydı $(p<0.05)$.

TARTIŞMA: Endotrakeal entübasyon savaş alanında GGG kullanarak karanlıkta uygulanabilir bir prosedürdür. Gece görüş gözlükleri ile karanlıkta yapılan tıbbi müdahaleler, taktik acil tıbbında verilen temel eğitimlerin bir parçası olmalıdır.

Anahtar sözcükler: Endotrakeal entübasyon; gece görüş gözlükleri; karanlık; savaş alanı.

Ulus Travma Acil Cerrahi Derg 2018;24(2):97-103 doi: 10.5505/tjtes.2017.27546 